KYLE MINOR

\title{
SEVEN STORIES ABOUT KENEL OF KOULÈV-VILLE
}

\section{The First Day I Met Kenel}

The kids at the orphanage said Kenel is a liar.

The man at the tree place said Kenel is the best translator in Ouest Province. No French in his English.

The missionaries said Kenel is bad news. When he was a child he was always breaking things. You should see the two ladies who raised him. They're both hunched over. He wore them out.

The Canadian dentist recommended Kenel. He said one day he was up in the mountains doing field dentistry, and this husband and wife came in with vampire teeth. Triangles that came to points. They said their teeth hurt, and Kenel said, "Don't fix the vampire teeth. Just do the fillings." But the dentist didn't listen. He restored the man's teeth and the woman's teeth to happy squares. He showed them in the mirror. He thought they'd be so happy. But the woman yelled and the man cried. Kenel listened and did his translating. Kenel said, "Get out the file. They want the vampire teeth back. There's a thing they do." The man pulled the neck of his shirt to his shoulder. There were hundreds of little scars, some of them fresh.

I paid Kenel seventy dollars a day. The other translators got fifty, but he said he had a thing for sevens. He said he had seven older brothers. When he was seven days old, seven women begged his father not to give him away to the two lady missionaries. They said seven curses would befall him.

"The first curse was the curse of English," Kenel said. We were walking the village Barette, taking the census of the rabbits and the chickens. "No Creole allowed. No French. Only English."

He spoke in English, read in English, wrote in English, watched movies in English, gave tours of the missionary compound to visiting Americans and Danes in English. "They said we're your mothers now," he said. "Children speak the language of their mothers."

The day he turned seventeen, the two missionary ladies drove him up the mountain to his father's house. They said, "Now you're grown. We've done all we can." Kenel said, "Aren't you my mothers?" They cried and drove away. His father came out of the house and cried and embraced him and spoke to him in a language he couldn't understand. "The second curse was the curse 
of Creole," Kenel said. "It took me seven years to speak it well enough to pass for a Haitian."

Up the hill was the houngan's house. His wooden roof was painted purple beneath a field of orange stars. I wanted to visit him and convince him to sell it to me to take to Florida. Kenel said, "If the houngan came to my village, we would have to kill him."

"Why?" I said.

"Because," Kenel said, "he does not have the love of Christ in his heart."

Later, I asked the elders of Kenel's village if they would kill the houngan. They laughed. "Kenel is a liar," they said. "The houngan is our friend. He goes to the church in Barette sometimes on Sundays when they need a trumpet player. The houngan is a good trumpet player."

In the village Barette, Kenel told me the third, fourth, fifth, and sixth curses. It was getting dark, and we were walking up out of the village. I asked him what was the seventh curse. "You see these people, all my neighbors? I have to live among them. You and me, we're not like them."

He headed up the hill a ways, and I followed him across the mountain to his home. From every house we passed, people called their greetings.

\section{Before the Earthquake}

This was before the earthquake reduced the Hotel Montana to rubble. We were sitting at the bar drinking Dominican beers, Jean-Pierre, Kenel, and me. The next morning we had to drive to Jacmel to count some rabbits and chickens. Kenel had a little cocaine, and I gave him a little money, and he gave me the cocaine, and I put it in my pocket for the morning.

We were playing a game called Who's More Heroic Than the Americans. It was a joke of a game. The first round everyone said: "Everyone who's not an American." The second round you had to tell another true story, but this one had to be specific.

"I knew a Catholic priest in Cité Soleil," Jean-Pierre said. "He was Nigerian. The people were so mean to him. This went on for years. They stole things from his house. Once, he was beaten in the street and no one came to his aid. Still, he lived seven years in a shanty house, even though he could have lived well. He could have lived anywhere. One day a little retarded boy was crossing an open sewer on a lashed-together bridge made of two halves of one tree. The sewer was five feet deep with water and every kind of human waste. People pissed in it, shit in it. The sewer was the color of disease. This 
little retarded boy couldn't have been more than five years old. Halfway across the bridge, some older boys came and shook both sides, just to be mean. The little retarded boy fell in. He was flailing around. There was a big crowd. People were watching him go down, but nobody wanted to jump in. Around the time the boy went over, the Nigerian priest came walking by. $\mathrm{He}$ didn't even hesitate. He didn't take off his clothes or his watch or take out his wallet or anything. He just jumped in, head-first, into the shitwater. $\mathrm{He}$ went under and came back up with that kid. That brown sludge was in his mouth, in his teeth, in his eyes."

"I can beat that," Kenel said. "I knew a man who took a blowtorch to the side of a shipping container somebody was using for a store in the village Marigot. The store owner caught him red-handed at midnight. His bag was filled up with biswuit, dry goods, Tampico juices, Coca-Colas. The store owner called for his cousins, and his cousins called for their cousins. Soon all the men of the village surrounded this man in the shipping container. They tied him up, and in the morning, they dragged him out into the middle of the road. They brought out all the children to see. The store owner said, 'See what happens when you steal.' While the man was still alive, they hacked off his fingers and toes one by one with a machete. They sealed the wounds with a hot iron. Then they hacked off his feet and hands. Then they hacked off his arms at the elbows and his legs at the knees. Then they poured gasoline over his head and set him on fire and watched him dance around while he died."

"The store owner was a hero," Jean-Pierre said, "for protecting his family business."

"No," Kenel said. "The thief was a hero, for risking his life to get food for his family."

They looked at me. I shielded my part of the table with my arm. I poured some of the powder on the table, made a line, and snorted. I said, "I wish I had some to share."

\section{After the Earthquake}

We went down to the mausoleum where Kenel's dead were buried. The earth had buckled in waves, and one of the waves split the center of the concrete, and where it had split, the fresh corpses had fallen out of their graves and mingled on the ground with the bones of the longer dead, and some carrion animals were pulling at a dead woman's face. The smell is in my nostrils still. 
At the graveside, I told Kenel I couldn't take this gruesome scene, this horror movie.

Kenel lifted the bodies from the ground one by one, and held them for a while. "Auntie Marie," he said. "Auntie Ti-ti. Auntie Solange."

\section{The Pig and the Pony}

We reached a vista. All of Port-au-Prince stretched out beyond us, the sun reflecting from the metal roofs of the bidonville shanties like a hundred thousand daytime stars. An American Airlines jet took off from the airport. Kenel said any child with a shoulder-fired rocket launcher could stand on any rooftop in La Saline and blow any airplane out of the sky. Why hadn't it happened yet?

A donkey draped with yellow saddlebags came up the road from the distance. A thin man in a yellow shirt led the donkey up the hill. He waved as he got closer. His shirt and the saddlebags said DHL in red letters. We said bonswa and komon ou ye and byen, byen. "What do you have?" Kenel said. "Letters," the DHL courier said. "Where is your motorcycle?" Kenel said. The DHL courier said the gas tank had rusted out, so he had replaced it with a gallon milk jug, but someone had dropped a match into the milk jug while he was making a delivery at the cement store.

After the DHL courier left, six men came up the hill carrying a casket. They were dressed in fine linen suits, and white specks from the dirt in the road were soiling their shoes, which were newly shined. We made room so they could pass us, and as they passed we briefly joined in their funeral song.

We watched them disappear behind a bend where the road followed the curve of the mountain, and when they were gone, I asked Kenel who was in the casket. "That is the wife of one of the elders of the village Jean-Baptiste," he said. "She fell in love with a bourgeois man in the city. Every day she took the tap-tap to see him. He gave her so much money. When the elder found out, he fed her feet to his pony."

Later I visited the village Jean-Baptiste and played soccer with some of the men who lived there. After the game, the women made a feast of rice and stewed tomatoes and a sauce of leeks and carrots. For me, they killed their fattest rabbit, and they would not take any money for it. While we were eating, I asked about the elder who fed his wife's feet to a pony. A man stood up and said, "Come, let me show you." We walked down the orange path, past his sister's house, his brother's house, the houses of his two friends and 
his one sworn enemy. A bone-thin pony was tied up in the front of his own house. He petted the pony and said, "The lies they are telling about you." Then we went to the backyard, where he kept two pigs, and he pointed to the fatter one. "It was this fellow who ate the feet," he said. "Not the pony."

We stared at the pig for a long time. I imagined the woman's feet in its mouth. Then the man laughed bitterly. "Do you think this is a village where we feed the parts of people to animals?" He said it to shame me.

When I told Kenel, he said, "Don't believe it. I don't trust that pony."

5. The Third, Fourth, Fifth, and Sixth Curses

Once, late at night, we were trying to sleep in the reclined seats of a borrowed Jeep in the middle of the treeless forest, on our way to cross the Dominican border. We both kept machetes under the seats, and I had a gun. Somewhere near enough to hear but not near enough to see, a lot of people were singing and beating drums. I kept the keys in the ignition.

Sometime before morning, Kenel said, "Tell me about your mother."

"She was a good woman," I said, "but for twenty years she refused to talk to her sister."

"Her sister slept with her husband?" Kenel said.

"No," I said. "It was a misunderstanding. Her sister forgot to pick me up from school one afternoon, and one time she left me alone in her house for a half hour while she went to the store to buy some groceries. There was an incident with somebody saying something to somebody else about what somebody else said to some other person. I'm not sure I understand it."

"After I was born, my mother ran away," Kenel said. "No one knows where. There was some kind of craziness in her family. My father said many of them had been turned into zombies. He took me to see them near Furcy. They were chained to a plow, four of them, and pulling it. My father said, 'That's voudou,' and I said, 'No, it's not. That's mental illness.' The farmer had a whip, but he wasn't driving them with it. He didn't need the whip. Their spirits were broken already. They were machines with broken brains."

He reached under his seat for his water bottle and took a sip. "Why are people so bad to each other?" he said. "There was this crazy woman. She always came into town with this mongrel dog. She only had one friend. He was a crazy person, too. A line of drool always hung from his mouth. He had gums instead of teeth. Sometimes he stole some food for her dog. I never saw her eat. She was always looking for food for the dog." 
Sometimes when I think of him, now, it's this moment. He's staring out the window in the direction of the mountains of Massif de la Selle, thinking about his mother.

"Sometimes she slept on the steps of the mission school. When she did, we stepped over her. Someone might poke her with his foot, to wake her. Someone probably kicked her sometime, but I never saw anyone do it.

"One morning the dog was gone. She was walking the street, looking for the dog. All day she was looking. The next morning, she lay on the steps of the mission school. I stepped over her. We all stepped over her. Nobody poked or kicked her. We let her sleep. We felt sorry for her, because of the dog.

"She was still lying there at the end of the school day, when they opened the doors and let us free. She didn't move the whole day, and then she didn't move the whole night. One of the teachers came along and covered her body with a black sheet. Nobody wanted to take her body. Nobody wanted her to live forever with their own dead. Nobody wanted her bones with their bones.

"Nobody claimed her body until the next morning. It was the crazy man who fed her dog. He lifted her body, sheet and all. He was talking to her. He had her under the armpits, and he started spinning with her. He was dancing with her. They were turning and turning. He was making a noise like an animal soon to the slaughter.

"People were yelling. Put her down, put her down! The boys picked up rocks and threw rocks at him. He had to flee. He tried to carry her away with him, but she was too heavy. The rocks were still coming. His face was bloody from them, and his shirt was torn. Finally, he dropped her in the grass by the side of the road. She lay there for three days, and then a Dutch man paid to have her buried in another village. He sent two men to collect her body.

"For a while I didn't think about her much. But after I saw her relatives chained to the plow, I thought: could that crazy woman have been my mother?"

\section{The Tumor}

The kids at the orphanage said why do you ride around with Kenel?

The missionaries said watch out. He wants things from you. He will steal things from you. Watch your guns. Watch your jewelry.

The man at the tree place told me about a cash-for-charcoal scam that ended in nobody getting any charcoal. The man at the art kiosk across the 
street from the mission told me about a middleman scheme. The man who built the wooden A-frame houses that were meant as temporary housing, but which the people who bought or received them meant to last a hundred years, told me about a strike-and-extortion scheme, which yielded nothing. "I have a hundred bodyguards," the man said, although he only had two. A farmer in Artiste told me of a scam where Kenel tried to sell electricity he was stealing by tying barbed wire to the new power lines the president was running up the mountainsides. "Does he think I don't have barbed wire?" the farmer said. "Everyone has barbed wire."

Almost every day, Kenel asked me for more money. He said his nephew needed money to give the school for photocopies. He said his niece needed money for needle and thread. He said the church needed money for sound equipment. He said his father needed money for a saw and a lathe and a level, so he could start a new business as a carpenter. He said he knew a man whose father had a tumor the size of a small grapefruit on his prostate. $\mathrm{He}$ said he needed money to take out the tumor and the prostate. "Let me see this man," I said. "Take me to see this man."

We walked down into Kenel's village. "Don't be alarmed," Kenel said, "when you see their eyes." All the members of the family had a degenerative eye disease. They all went blind by age twenty-five. "My friend is twentythree," Kenel said. "You can see it already. The disease is eating his eyes."

There were eight small children, two teenage girls, Kenel's friend, and his father and mother, both of whom were in their seventies. Kenel's friend was a very late child. ("A miracle child," I said. "A shame and a burden," Kenel said.) The teenage girls and the children were the sons and daughters of sons and daughters and grandsons and granddaughters who had long since fled for the city. These were the unwanted children, or the too-many children, or the children taken early by the blindness. Kenel's friend was working for tips at the Hotel Kinam to bring in money, and tending the garden in the mornings. When he was gone, people stole from the garden. There was no one in the family able enough to do anything about it.

We greeted Kenel's friend. "My friend," he said, "my good friend. You will come see my father."

He led us through a maze of banana trees, past the hundred-year-old stone house, to the unfinished concrete house at the back of the property. It had holes for windows and a hole where the roof would go. The old man sat 
shaking in a chair at the center of the one room. Piles of construction sand filled the four corners.

The old man leaned on his cane and shook. He waved us near him and spoke. He had the breath of brown death. After he said half a sentence, he paused to catch his breath, and Kenel translated. "I saw you in a dream," he said. "Bondye sent you from America. Your journey took you over the sea. You are estranged from your mother. You are wearing glasses and you have beautiful shoes." Most of these things were true. "Bondye said this man will come," he said. "You will show him your wound. He will lay hands on your wound, and your wound will be healed."

He pushed on his cane. With some effort, he sat upright in his chair. With his shaking hand, he handed the cane to his son. With great effort, he reached both hands to his pants button and his zipper. He said, "I will show you." He unbuttoned his pants, and he unfastened his zipper. With both hands, as if presenting a bouquet of flowers, he held himself out to us. What he showed was mostly tumor. His penis and his testicles had shriveled to a flaccid tininess. Most of his hair had fallen away. Only a slight smear of peach fuzz remained, and it was slick with a yellowish-white discharge from a suppurating wound that was on the tumor but not of the tumor.

"Bondye said," the old man repeated, "this man will come. You will show him your wound. He will lay hands on your wound, and your wound will be healed."

Everyone was looking at me. Kenel, with his good eyes. The man's son, with his cataracting, failing eyes. The old man, with his blind eyes. Even the tumor seemed like a giant dying eye. The man's son was nodding, as if to say: go ahead. Kenel was watching, as if to see what kind of man I was after all our time together.

I held out my hands. I cupped them as if I were preparing to draw water from the river. I put them on either side of the tumor. My right wrist grazed the old man's tiny penis, and my left wrist grazed his testicles. The skin swollen by the tumor was hot, and the skin covering the genitals was as cold as a slab at the morgue. "You must pray," the son said. "Our Father, who art in heaven," I said. It wasn't a prayer to the sky. It was a prayer to the people in the room. If there was any belief to borrow, it was all theirs.

Then I couldn't remember the rest of the words to the prayer, even though it was the most famous prayer in the world. In my mind, it had become conflated with a less famous poem, by an American who had once been my 
teacher at the university. Our Father who art in heaven, I am drunk. Again. Red wine. For which I offer thanks. I ought to start with praise, but praise comes hard to me. I stutter...

I had not memorized the whole poem, but I did remember the ending, the beautiful ending. The drunk, praying, thinks of himself as an old-time cartoon character, a poor jerk who wanders out on air and then looks down. Below his feet, he sees eternity, and suddenly his shoes no longer work on nothingness, and down he goes. The drunk prays: As I fall past, remember me.

It seemed as fitting a prayer as the one I had forgotten. I cobbled together bits and pieces of both, and drew on the language of special pleading I remembered from all those dreary years at the Cherry Road Baptist Church. I used the words suppurating, and grapefruit, and hot and cold, and shrivel and shrink.

When I was done, nothing happened. Everyone was as blind or cataracted or tumored or lying or despicable as we had been before we prayed, and my hands were wet with white and yellow pus. I told the old man I was sorry. Nothing happened. He had not been healed. I must not be the man Bondye had sent from over the sea. He said, "We must wait. Bondye's time is not our time."

Outside, I asked Kenel, "How much is the surgery?"

Kenel said, "All surgeries are three hundred dollars."

I said, "I have four hundred dollars in my pocket. I'm going to give all of it to him."

Kenel said, "If you give him four hundred dollars for his surgery, they will use it to buy sand and Portland. Or they will use it to buy a window. Or they will use it to buy corrugated aluminum for a roof. The old man will die soon no matter what you do."

"What can I do?" I said.

"You can give the money to me," Kenel said. "I will take it to pay the doctor, and I will pay the tap-tap to take him to the doctor."

I looked at him, and I knew. He would take the money and put it in his pocket, and I would never see him again. Or I would see him again the next time he wanted some money.

"No," I said, quietly. "No, no."

I put the money back in my pocket and vowed to return after we did the count in Mirebalais_-in three weeks. Pick up the old man myself. Take him to the hospital myself. Pay for the surgery myself. 
In later years, a woman told me: Who do you think you are, to play God? Who do you think you are, the savior of the world? I said: I only wanted to save this one man for a little while. I knew he was going to die soon.

Three weeks passed. We returned to the village. Another casket, a cheap one, was marching up the street. So many of the pallbearers were blind. "Don't worry," Kenel said. "You took his tumor in your hands." "But I didn't cut it out," I said. "You should have given me the money," he said.

\section{At the Marché}

A few days later we went to the Marché en Fer to buy fruits and vegetables. The whole market had fallen down in the earthquake, but now an Irishman had rebuilt the clock tower and the minarets, restored the masonry, and reinforced the iron columns. The Irishman said the new walls were earthquakeproof, and the roof was covered with solar panels.

These were the days when it was hard to walk into a building and not be afraid the walls and the roof might fall on you and crush your head. You looked for a space beside a sturdy piece of furniture and traced an invisible line at a forty-five degree angle, which you'd dive beneath for shelter at the first shake. Every so often, continuing to this day, another building would fall in an aftershock. All over the country we saw three-story buildings pancaked to one story, and lo these years later, the bodies still inside. They didn't even stink anymore. Almost for certain, the bacteria and the worms and the rodents had picked them to bones.

But it wasn't like the early days. People were moving. Children in uniforms walked to school in the mornings. The tap-taps were full of men carrying their work tools in canvas bags. In the city, the cell phone vendors walked the streets in their red smocks and carrying their red phones, selling rechoj cards, and soda and water vendors walked through the traffic jams, carrying on their heads cardboard boxes full of plastic sugar-and-caffeine concoctions and vacuum-sealed plastic bags of water.

In the Marché, I bought two bottles of Atomic Energy Drink, one for me and one for Kenel, and he bought me a Styrofoam container full of griot and fried plantains and pikliz. I bought him a pizza from a vendor billing herself as the Walt Disney Pizza Company. Famous mice and dogs and ducks decorated the sign behind her.

We took our food outside and crouched in the shade of the nearest wall. While we were eating, Kenel said, "When you leave, will you come back?" 
I stopped eating for a moment. An uncharacteristic sincerity was in his eyes. I didn't trust it.

"You are my good friend," he said.

But that's what everyone said. Everyone who wanted something. I could see myself, in a few weeks, sitting on my couch in Florida, watching football. The job was over. There was no reason for me to stay. "What will you do," I asked, "after I leave?"

He patted his wallet, where he kept some of his walking-around money, and he patted his shoe, where he kept the rest. "I have met some important people," he said. He pointed at every ten degrees of the sky around us. "I'm going to buy a new suit. The future is big."

Already he had gathered ten of the best English speakers in Koulèv-Ville. He planned to drill them six days a week, in the mornings, when the mind is still fresh. He planned to lease them by the day to journalists and tourists and aid organizations of every stripe, with special rates for weekly or monthly hires. He would take twenty percent as his fee. No longer would he be the wage worker. Now he would be the collector of the real money, the wage-giver, the big boss.

"When you get home," Kenel said, "you will not remember me."

Within six months, he would be dead. The rally at the Palace. The fires. The burning tires. The gunshots, two to the head.

That day at the Marché, he said, "It's going to be the most beautiful suit. It's going to be linen. It's going to be chalk-striped, double-breasted. It's going to have a notched lapel. I'm going to get it tailored." 